\title{
The $2 b$ Protein of Cucumoviruses Has a Role in Promoting the Cell-to-cell Movement of Pseudorecombinant Viruses
}

\author{
Bu-Jun Shi, ${ }^{1,2}$ Jane Miller, ${ }^{3}$ Robert H. Symons, ${ }^{1}$ and Peter Palukaitis ${ }^{3}$ \\ ${ }^{1}$ Department of Plant Science, Waite Institute, Adelaide University, Glen Osmond, SA 5064, Australia; ${ }^{2}$ Department \\ of Molecular Bioscience, Adelaide University, Adelaide, SA. 5005, Australia; ${ }^{3}$ Scottish Crop Research Institute, \\ Invergowrie, Dundee, DD2 5DA, United Kingdom
}

Submitted 16 September 2002. Accepted 4 December 2002.

\begin{abstract}
Pseudorecombinant viruses (i.e., those containing a reassorted genome of closely related multipartite viruses) are often not as competitive as the parental viruses. The role of the $2 b$ gene in hypervirulence and maintenance of a progressive infection was assessed in a pseudorecombinant virus formed between RNAs 1 plus 2 of Cucumber mosaic virus (CMV) and RNA 3 of Tomato aspermy virus (TAV). The presence of RNA 3 of TAV was found to affect the level of RNA accumulation but not the level of virulence. By contrast, the $2 b$ genes of both TAV and a hypervirulent strain of CMV (WAII-CMV) were found to affect the virulence of the pseudorecombinant viruses but not the levels of viral RNA accumulation. The $2 b$ gene rather than the overlapping open reading frame encoding the $C$-terminal 41 amino acids of 2 a protein of the corresponding virus was found to be essential for promoting infection of the pseudorecombinant viruses in planta. However, the $2 b$ gene was not essential for replication of pseudorecombinant viruses containing CMV RNAs 1 plus 2 and TAV RNA 3. These results indicate that the $2 \mathrm{~b}$ protein is involved in promoting the cell-to-cell movement of the pseudorecombinant viruses. These data also suggest the existence of specific interaction between the TAV $2 b$ protein and either RNA 3 or its encoded proteins, which may be critical for promoting or maintaining infection or both.
\end{abstract}

Mixed infections of plants by two or more unrelated viruses are quite common, sometimes leading to synergistic interactions. By contrast, when two viruses are closely related in sequence, there is usually some form of competition between them, often leading to the loss of one of the viruses. Several examples of such virus exclusion have been observed for plants infected by viruses in the genus Cucumovirus (Sackey and Francki 1990; Crescenzi et al. 1993; Fraile et al. 1997). Sackey and Francki (1990) observed that mixed infections in several common hosts by the cucumoviruses Cucumber mosaic virus (CMV) and Tomato aspermy virus (TAV) led to loss of TAV upon passage but almost never loss of CMV. Similarly, altering the initial ratios of the two viruses in the inoculum in favor of TAV still resulted in infection by either CMV alone or both viruses but rarely by

Corresponding author: P. Palukaitis; Telephone: +44 1382 568523; Fax: +44 1382 568575; E-mail: ppaluk@scri.sari.ac.uk.

* The $\boldsymbol{e}$-Xtra logo stands for "electronic extra" and indicates Figures 3 and 4 appear in color on-line.
TAV alone. This difference in selective advantage of CMV over TAV also extended to pseudorecombinant viruses (i.e., with reassorted genomes) formed between the three genomic RNAs of CMV and TAV (Sackey and Francki 1990). A pseudorecombinant virus consisting of RNAs 1 and 2 of CMV and RNA 3 of TAV (C1C2T3) was completely unable to compete with CMV in mixed infections. Similarly, the reciprocal pseudorecombinant virus T1T2C3 was unable to outcompete CMV, even when inoculated in a 19-fold excess. The inability of such viruses to maintain a long-term coexistence, either in the initially inoculated plants or upon passage, was concluded to be a consequence of differences in the rates of systemic infection by the virus combinations (Sackey and Francki 1990). If one virus is able to outpace host defense responses more efficiently than the other virus, the former virus may be able to gain a competitive advantage.

The $2 b$ gene of different cucumoviruses has been shown to have a major effect on systemic infection by CMV as well as on the degree of virulence (Ding et al. 1995a, 1996; Ji and Ding 2001; Shi et al. 2002; Soards et al. 2002). These effects are believed to be due to the ability of the $2 \mathrm{~b}$ protein to inhibit various defense reactions, such as by interference with the salicylic acid-mediated defense response (Ji and Ding 2001) and by suppression of the RNA silencing mechanism (Brigneti et al. 1998; Guo and Ding 2002). The approximately 11- to 13$\mathrm{kDa} 2 \mathrm{~b}$ protein has been localized to the nucleus (Mayers et al. 2000), and mutations affecting its nuclear localization also affected the ability of the $2 \mathrm{~b}$ protein to suppress RNA silencing (Lucy et al. 2000). The $2 \mathrm{~b}$ protein also may be considered a determinant of host specificity (Ding et al. 1995a; Li et al. 1999; Shi et al. 2002).

The $2 b$ gene of TAV also has been shown to be a determinant of virulence, when expressed either from CMV in place of its own $2 b$ gene (Ding et al. 1996) or from virus vectors such as Tobacco mosaic virus and Potato virus $X$ (Li et al. 1999). On the other hand, wild-type TAV itself did not display the hypervirulence associated with the expression of its $2 b$ gene from other viruses. Therefore, such hypervirulence may be associated with some incompatibility between one of the roles of the TAV $2 b$ gene and components of the other viral genomes, including that of CMV. The failure of the CMVTAV pseudorecombinant viruses to compete effectively with either parental virus (Sackey and Francki 1990) suggests a possible $2 \mathrm{~b}$ protein function that can be assessed; viz., the role of the $2 \mathrm{~b}$ protein in maintaining a progressive infection of CMV-TAV pseudorecombinant viruses. Here, we examine this role and confirm that, while the $2 b$ gene itself is not 
essential for movement of CMV in young plants of two Nicotiana spp. (Ji and Ding 2001; Soards et al. 2002), the $2 b$ gene is essential for movement of a pseudorecombinant virus derived from CMV RNAs 1 and 2 and TAV RNA 3.

\section{Plasmid Structure}

pQCD2 (C2)

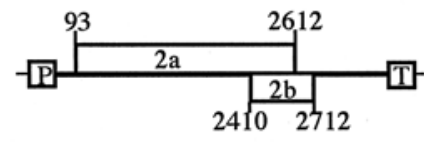

pQCD2qt $\left(\mathrm{C}_{\mathrm{q}}\right)$

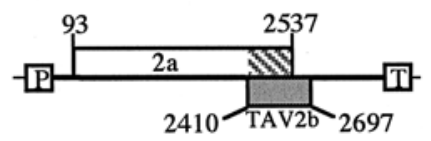

pQCD2qt1 $\left(\mathrm{C}_{\mathrm{qt1}}\right)$

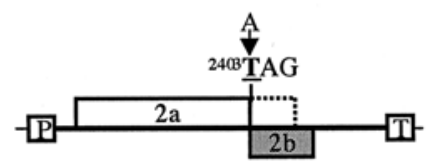

pQCD2qt2 $\left(\mathrm{C}_{\mathrm{qt} 2}\right)$

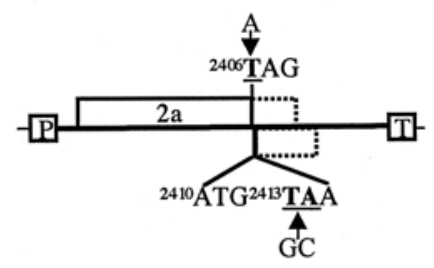

pQCD2qt3 $\left(\mathrm{C}_{\mathrm{q} 13}\right)$

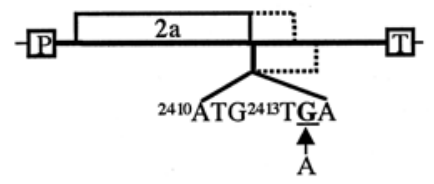

pQCD2qw $\left(\mathrm{C}_{\text {qw }}\right)$

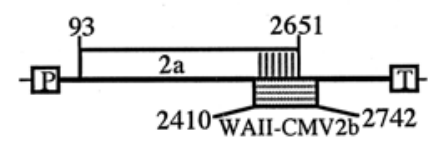

Fig. 1. Schematic representation of cucumber mosaic virus (CMV) RNA2 mutants. The various plasmids containing either the wild-type $2 \mathrm{~b}$ open reading frame (ORF) of the Q-strain of CMV (plasmid pQCD2) or variants of the $2 \mathrm{~b}$ ORF in Q-CMV RNA 2, as shown. The $2 \mathrm{~b}$ ORF and overlapping Cterminus of the 2a ORF of Q-CMV were replaced with the corresponding sequences from either the WAII-strain of CMV or Tomato aspermy virus (TAV) in pQCD2qw and pQCD2qt, respectively. A termination codon was introduced into the sequences encoding the overlapping $\mathrm{C}$-terminus of the TAV 2a protein to prevent the expression of these sequences in pQCD2qt1. Different termination codons were then introduced into $\mathrm{pQCD} 2 \mathrm{qt} 1$ to prevent expression of the TAV $2 b$ ORF, creating pQCD2qt2 and pQCD2qt3. The nucleotides introduced to generate termination codons are shown in bold and underlined. Arrows indicate the substituted nucleotides. The stop codon of the $2 \mathrm{a}$ ORF and the start and stop codon of the $2 \mathrm{~b}$ ORF are indicated by nucleotide position numbers. All of the plasmids contained the respective Q-CMV RNA 2 cDNA flanked by cauliflower mosaic virus $35 \mathrm{~S}$ RNA promoter $[\mathrm{P}]$ and terminator $[\mathrm{T}]$ sequences.

\section{RESULTS}

RNA 3 of TAV affects accumulation levels

of CMV RNAs 1 and 2 but not virulence.

The effects of the genes encoded by TAV RNA 3 on the virulence of CMV as well as on the accumulation of viral RNAs were analyzed to explore the potential interactions during infection of the proteins encoded by RNA 3, the 3a protein, and the capsid protein (CP), either alone or in combination, with the proteins encoded by CMV RNAs 1 and 2, the 1a, 2a, and 2b proteins. Thus, the pseudorecombinant cucumovirus designated C1C2T3 was constructed. Here, C and T indicate the Q-strain of CMV and the V-strain of TAV, respectively, and 1, 2, and 3 indicate RNAs 1, 2, and 3, respectively, all derived from infectious cDNA clones (Ding et al. 1995b; Shi et al. 1997a). Initially, the differences were examined in the context of a wild-type Q-CMV RNA 2 background, before assessing the effects of chimeric RNA 2 containing the TAV $2 b$ gene inserted in Q-CMV RNA 2 (i.e., comparing pQCD2 with pQCD2qt [Fig. 1]).

Bioassay of C1C2C3 (i.e., Q-CMV RNAs 1 through 3) and C1C2T3 on two Nicotiana species, N. clevelandii and N. glutinosa, indicated that both viruses were infectious and induced either no systemic symptoms or similar mild systemic symptoms (Table 1). Analysis of the accumulation levels of these two viruses in $N$. glutinosa showed that they both accumulated, although RNAs 1 and 2 of Q-CMV accumulated to higher levels in plants infected by $\mathrm{C} 1 \mathrm{C} 2 \mathrm{~T} 3$ than in plants infected by C1C2C3 (Fig. 2A, lane 5 vs. lane 2). On the other hand, the level of accumulation of TAV RNA 3 was similar or slightly lower for C1C2T3 than for T1T2T3 (i.e., V-TAV RNAs 1 through 3 [Fig. 2B, lane 5 vs. lane 3]). Nevertheless, T1T2T3 induced more severe systemic symptoms than either $\mathrm{C} 1 \mathrm{C} 2 \mathrm{C} 3$ or C1C2T3 (Table 1 and Fig. 3A). Thus, the increase in accumulation of $\mathrm{C} 1$ and $\mathrm{C} 2$ in the presence of T3 did not parallel an increase in the severity of symptoms. This is consistent with earlier observations suggesting that the symptom determinants of TAV were associated with either RNA 1 or 2 or both (Habili and Francki 1974; Salánki et al. 1997).

The $2 b$ gene affects virulence but not RNA accumulation, independent of the source of the RNA 3.

The $2 \mathrm{~b}$ open reading frame (ORF) of Q-CMV RNA 2 was replaced with that of TAV to construct pQCD2qt (Fig. 1). The plasmid pQCD2qt was combined with pQCD1 plus pQCD3 or pQCD1 plus pCass1T3 and was inoculated to plants to generate the viruses $\mathrm{C} 1 \mathrm{C} 22_{\mathrm{qt}} \mathrm{C} 3$ or $\mathrm{C} 1 \mathrm{C} 2_{\mathrm{qt}} \mathrm{T} 3$. Comparison of the symptoms induced on both $N$. glutinos $a$ and $N$. clevelandii by the three viruses, $\mathrm{C} 1 \mathrm{C} 2 \mathrm{~T} 3, \mathrm{C} 1 \mathrm{C} 2_{\mathrm{qt}} \mathrm{T} 3$, and $\mathrm{C} 1 \mathrm{C} 2{ }_{\mathrm{qt}} \mathrm{C} 3$, showed that both $\mathrm{C} 1 \mathrm{C} 22_{\mathrm{qt}} \mathrm{T} 3$ and $\mathrm{C} 1 \mathrm{C} 2{ }_{\mathrm{qt}} \mathrm{C} 3$ induced similar systemic symptoms, more severe than those induced by $\mathrm{C} 1 \mathrm{C} 2 \mathrm{~T} 3$ or T1T2T3 (Table 1 and Fig. 3A). On the other hand, the chimeric cucumoviruses $\mathrm{C} 1 \mathrm{C} 22_{\mathrm{qt}} \mathrm{T} 3$ and $\mathrm{C} 1 \mathrm{C} 2{ }_{\mathrm{qt}} \mathrm{C} 3$ showed quite different levels of accumulation of RNAs 1 plus 2 from each other (Fig. $2 \mathrm{~A}$, lane 6 vs. lane 7). Moreover, the virus pair $\mathrm{C} 1 \mathrm{C} 2 \mathrm{C} 3$ plus $\mathrm{C} 1 \mathrm{C} 2{ }_{\mathrm{qt}} \mathrm{C} 3$ accumulated similar levels of CMV RNAs (Fig. 2A, lanes 2 and 6) as did the virus pair $\mathrm{C} 1 \mathrm{C} 2 \mathrm{~T} 3$ plus $\mathrm{C} 1 \mathrm{C} 2{ }_{\mathrm{qt}} \mathrm{T} 3$ (Fig. 2A, lanes 5 and 7). Similarly, the latter two viruses also accumulated similar levels of TAV RNA 3 (Fig. 2B, lanes 5 and 7). This shows that the level of accumulation of RNAs 1 plus 2 of CMV was affected by the source of RNA 3 (TAV vs. CMV) but was not affected by the source of the TAV $2 b$ gene (Fig. 2A, lanes 2, 5, 6, and 7). These data also suggest that the $2 \mathrm{~b}$ protein may have determined the difference in virulence between the two viruses but was not influenced by the 3 a protein or CP derived from TAV RNA 3 (Table 1).

The replacement of the $2 \mathrm{~b}$ ORF also resulted in a change in the encoded C-terminal 41 amino acids of the 2 a protein from 
that of Q-CMV to that of TAV (Fig. 1). Hence, the chimeric 2a protein might have shown some effect on the virulence. Therefore, the pseudorecombinant, chimeric virus $\mathrm{C} 1 \mathrm{C} 2_{\mathrm{qt} 1} \mathrm{~T} 3$ was constructed to distinguish between the role of the TAV $2 \mathrm{~b}$ protein and the chimeric 2 a protein in determining hypervirulence. $\mathrm{C} 1 \mathrm{C} 2_{\mathrm{qt} 1} \mathrm{~T} 3$ was generated after infection by the plasmids pQCD1, pQCD2qt1, and pCass1T3. Plasmid pQCD2qt1 was a modification of pQCD2qt, in which a termination codon was introduced in the $2 \mathrm{a}$ ORF immediately upstream of the $2 \mathrm{~b}$ ORF and that would prevent expression of the C-terminal 41 amino acids of the 2 a protein (Fig. 1). Inoculation of $\mathrm{C} 1 \mathrm{C} 2_{\mathrm{qt} 1} \mathrm{~T} 3$ to the above two Nicotiana species showed that $\mathrm{C} 1 \mathrm{C} 2_{\mathrm{qt} 1} \mathrm{~T} 3$ was infectious, induced severe symptoms similar to those of $\mathrm{C} 1 \mathrm{C} 2{ }_{\mathrm{qt}} \mathrm{T} 3$ on the same plant species, and accumulated to levels similar to $\mathrm{C} 1 \mathrm{C} 2_{\mathrm{qt}} \mathrm{T} 3$ (Table 1 and data not shown). Sequence analysis of the progeny RNA 2 revealed that the mutation introduced was maintained (data not shown). Thus, the C-terminal 41 amino acids derived from the TAV 2a ORF did not influence the hypervirulence phenotype per se. This is consistent with earlier observations that the C-terminal 41 amino acids of the 2 a protein were not essential for systemic infection (Ding et al. 1995a).

\section{The $2 b$ gene is essential for promoting infection in planta of pseudorecombinant viruses containing CMV RNAs 1 and 2 and TAV RNA 3.}

Neither the C-terminal 41 amino acids of the 2 a protein nor the $2 \mathrm{~b}$ protein of $\mathrm{Q}-\mathrm{CMV}$ were required for either replication or cell-to-cell movement but did influence the long-distance movement of Q-CMV (Ding et al. 1995a; Ji and Ding 2001). Therefore, to establish the role of the $2 b$ gene in maintaining a pseudorecombinant virus, the virus $\mathrm{C} 1 \mathrm{C} 2_{\mathrm{q} 22} \mathrm{~T} 3$ was constructed and bioassayed. $\mathrm{C} 1 \mathrm{C} 2_{\mathrm{qt} 2} \mathrm{~T} 3$ was generated from the plasmids pQCD1, pQCD2qt2, and pCass1T3. Plasmid pQCD2qt2 contains termination codons introduced in both the $2 a$ and $2 b$ ORFs, such that neither the $2 \mathrm{~b}$ protein nor the C-terminal 41 amino acids of the $2 \mathrm{a}$ protein would be expressed (Fig. 1).

Surprisingly, the virus $\mathrm{C} 1 \mathrm{C} 2_{\mathrm{qt} 2} \mathrm{~T} 3$ did not appear to be infectious (Table 1; Fig. 2A, lane 9; and Fig. 2B, lane 9). Repeated inoculation of $\mathrm{C} 1 \mathrm{C} 2_{\mathrm{qt} 2} \mathrm{~T} 3$ with increased concentration up to five times the standard inoculum dosage still failed to demonstrate infection on $N$. clevelandii, $N$. glutinosa, or other plant species, including Lycopersicon esculentum and Physalis flori-

Table 1. Symptoms induced by various viruses in two Nicotiana spp. ${ }^{\mathrm{a}}$

\begin{tabular}{|c|c|c|}
\hline Viruses species $^{b}$ & N. clevelandii & N. glutinosa \\
\hline $\mathrm{C} 1 \mathrm{C} 2 \mathrm{C} 3$ & tMot or NS & tMot \\
\hline T1T2T3 & Mos & Mos \\
\hline C1C2T3 & tMot or NS & tMot \\
\hline $\mathrm{C} 1 \mathrm{C} 22_{\mathrm{qt}} \mathrm{C} 3$ & $\mathrm{Mos} / \mathrm{LD} / \mathrm{St}$ & $\mathrm{Mos} / \mathrm{LD} / \mathrm{St}$ \\
\hline $\mathrm{C} 1 \mathrm{C} 22_{\mathrm{qt}} \mathrm{T} 3$ & $\mathrm{Mos} / \mathrm{LD} / \mathrm{St}$ & $\mathrm{Mos} / \mathrm{LD} / \mathrm{St}$ \\
\hline $\mathrm{C} 1 \mathrm{C} 22_{\mathrm{qt} 1}^{\mathrm{q}} \mathrm{C} 3$ & $\mathrm{Mos} / \mathrm{LD} / \mathrm{St}$ & $\mathrm{Mos} / \mathrm{LD} / \mathrm{St}$ \\
\hline $\mathrm{C} 1 \mathrm{C} 22_{\mathrm{qt} 1} \mathrm{~T} 3$ & $\mathrm{Mos} / \mathrm{LD} / \mathrm{St}$ & $\mathrm{Mos} / \mathrm{LD} / \mathrm{St}$ \\
\hline $\mathrm{C} 1 \mathrm{C} 22_{\mathrm{q} 22} \mathrm{C} 3$ & tMot or NS & tMot \\
\hline $\mathrm{C} 1 \mathrm{C} 22_{\mathrm{q} 2} \mathrm{~T} 3$ & NS & NS \\
\hline $\mathrm{C} 1 \mathrm{C} 2{ }_{\mathrm{qt} 3} \mathrm{C} 3$ & tMot or NS & tMot \\
\hline $\mathrm{C} 1 \mathrm{C} 2_{\mathrm{q} 3 \mathrm{~T}} \mathrm{~T} 3$ & NS & NS \\
\hline $\mathrm{C} 1 \mathrm{C} 22_{\mathrm{qw}} \mathrm{C} 3$ & $\mathrm{Mos} / \mathrm{LD} / \mathrm{St}$ & $\mathrm{Mos} / \mathrm{LD} / \mathrm{St}$ \\
\hline $\mathrm{C} 1 \mathrm{C} 2_{\mathrm{qw}} \mathrm{T} 3$ & $\mathrm{Mos} / \mathrm{LD} / \mathrm{St}$ & $\mathrm{Mos} / \mathrm{LD} / \mathrm{St}$ \\
\hline
\end{tabular}

${ }^{\mathrm{a}}$ Systemic symptoms: tMot = transient mottle; Mos = mosaic; $\mathrm{LD}=$ leaf distortion; $\mathrm{St}=$ stunting; and NS = no symptoms.

${ }^{\mathrm{b}}$ Virus species derived from combinations of RNAs 1, 2, and 3 of the Qstrain of Cucumber mosaic virus (CMV) or the V-strain of Tomato aspermy virus (TAV), indicated here as $\mathrm{C}$ or $\mathrm{T}$, respectively. Mutants of Q-CMV RNA 2 consist of various replacements of the sequences encoding the $2 b$ gene with those derived from the corresponding gene of V-TAV or the WAII-strain of CMV, indicated by C 2 followed by the subscripts qt and qw, respectively. dana (data not shown). Failure to infect these plant species was confirmed by Northern blot hybridization analysis, which did not detect viral RNA in the inoculated plants (Fig. 2, lane 9 and data not shown). However, when pQCD2qt2 was combined with pQCD1 and pQCD3, the resultant virus, $\mathrm{C} 1 \mathrm{C} 22_{\mathrm{qt} 2} \mathrm{C} 3$, was infectious in $N$. glutinosa (Table 1 and Fig. 2A, lane 8) and in the other plant species tested (Table 1 and data not shown). Moreover, $\mathrm{C} 1 \mathrm{C} 22_{\mathrm{q} 2} \mathrm{C} 3$ accumulated to similar levels as $\mathrm{C} 1 \mathrm{C} 2_{\mathrm{qt}} \mathrm{C} 3$ (Fig. 2, lane 8 vs. lane 6). This indicates that
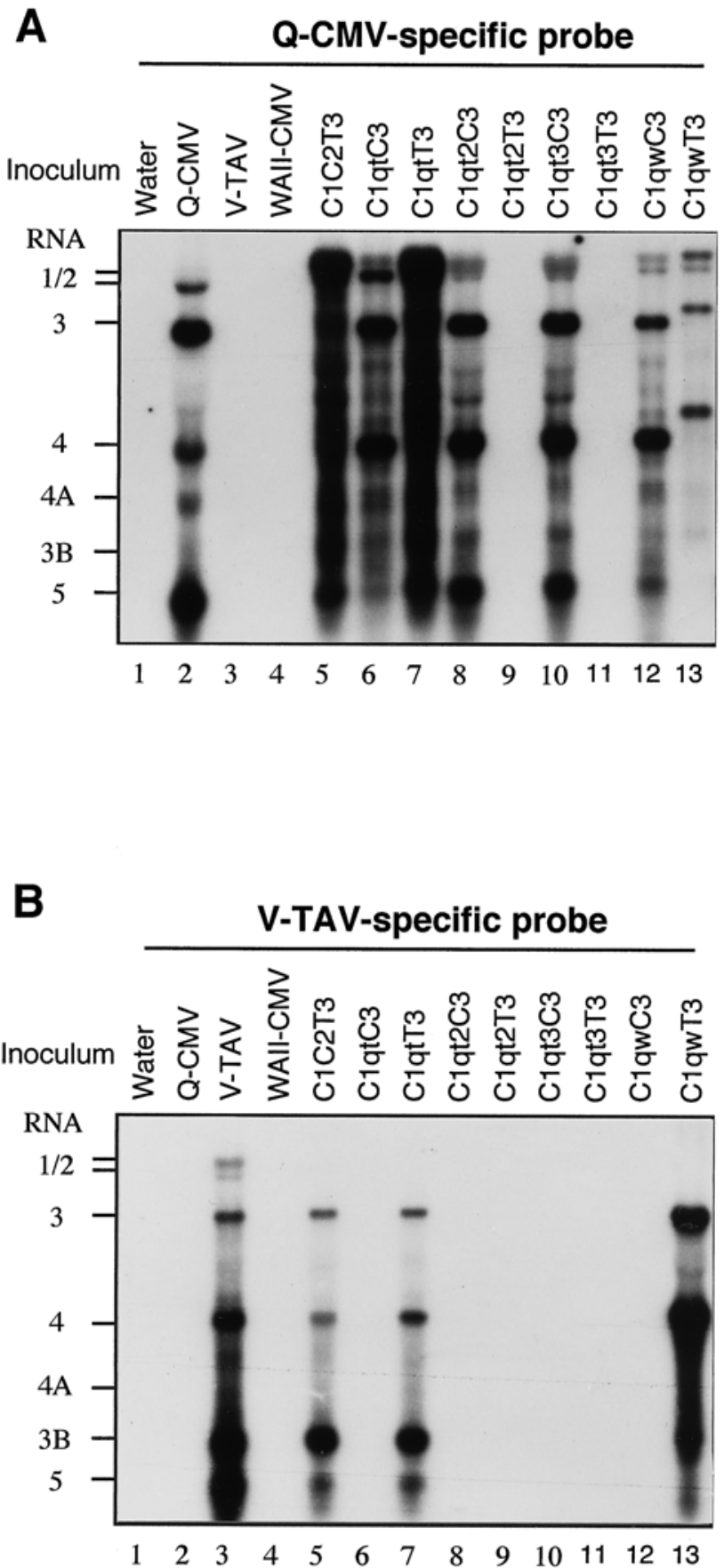

Fig. 2. Northern blot hybridization analysis of the accumulated viral RNAs in Nicotiana glutinosa. Total RNAs were extracted from N. glutinosa plants inoculated with the wild-type, pseudorecombinant, chimeric, or chimeric pseudorecombinant viruses indicated. Equal amounts of total RNAs were fractionated by electrophoresis, were blotted to membranes, and were hybridized with probes specific to the $3^{\prime}$ nontranslated region of the RNAs of either the Q-strain of Cucumber mosaic virus or Tomato aspermy virus. The positions of RNAs 1, 2, 3, 4, 4A, 3B, and 5 are indicated. 
pQCD2qt2 was biologically active but did not support a progressive infection with TAV RNA 3.

To confirm that the lack of infectivity of $\mathrm{C} 1 \mathrm{C} 2{ }_{\mathrm{qt} 2} \mathrm{~T} 3$ was not due to some effect of the two substituted nucleotides in pQCD2qt2, another virus, $\mathrm{C} 1 \mathrm{C} 2_{\mathrm{qt} 3} \mathrm{~T} 3$, was constructed in which the second substituted nucleotide, $A$, was changed to $\mathrm{G}$ (Fig. 1, pQCDqt3). Inoculation of $\mathrm{C} 1 \mathrm{C} 2_{\mathrm{qt} 3} \mathrm{~T} 3$ onto both test Nicotiana species showed that this virus also was not infectious (Table 1; Fig. 2, lane 11; and data not shown). However, when pQCD2qt3 was combined with pQCD1 and pQCD3, the resultant virus, $\mathrm{C} 1 \mathrm{C} 2_{\mathrm{qt} 3} \mathrm{C} 3$, infected both of the tested Nicotiana spp. (Table 1; Fig. 2A, lane 10; and data not shown), indicating that the plasmid pQCD2qt3 also was biologically active. Moreover, $\mathrm{C} 1 \mathrm{C} 2_{\mathrm{q} 13} \mathrm{C} 3$ accumulated to similar levels as $\mathrm{C} 1 \mathrm{C} 2_{\mathrm{qt}} \mathrm{C} 3$ (Fig. 2A, lane 10 vs. lane 6). These results indicate that the substituted nucleotide had no role in viral infection and further suggest the existence of a specific interaction between the TAV $2 \mathrm{~b}$ protein and RNA 3 that may be critical for viral infection. However, these studies could not differentiate between effects on either the replication of TAV RNA 3 or the cell-tocell movement of the chimeric viruses $\mathrm{C} 1 \mathrm{C} 2_{\mathrm{qt} 2} \mathrm{~T} 3$ and $\mathrm{C} 1 \mathrm{C} 2{ }_{\mathrm{qt} 3} \mathrm{~T} 3$.

\section{The $2 b$ gene is not essential for replication of pseudorecombinant viruses containing CMV RNAs 1 plus 2 and TAV RNA 3.}

Infectious plasmids yielding $\mathrm{C} 1 \mathrm{C} 2 \mathrm{C} 3$ or $\mathrm{T} 1 \mathrm{~T} 2 \mathrm{~T} 3$ after inoculation to whole plants did not yield viral RNAs after inoculation to protoplasts (B. J. Shi and R. H. Symons, unpublished data). Therefore, replication of $\mathrm{C} 1 \mathrm{C} 22_{\mathrm{qt} 2} \mathrm{~T} 3$, incapable of expressing the C-terminal 41 amino acids of the $2 a$ gene and the entire $2 \mathrm{~b}$ ORF, was assessed using a fluorescent assay in inoculated plants. The $C P$ gene in pCass1T3 was replaced with the gene encoding the green fluorescent protein (GFP), and

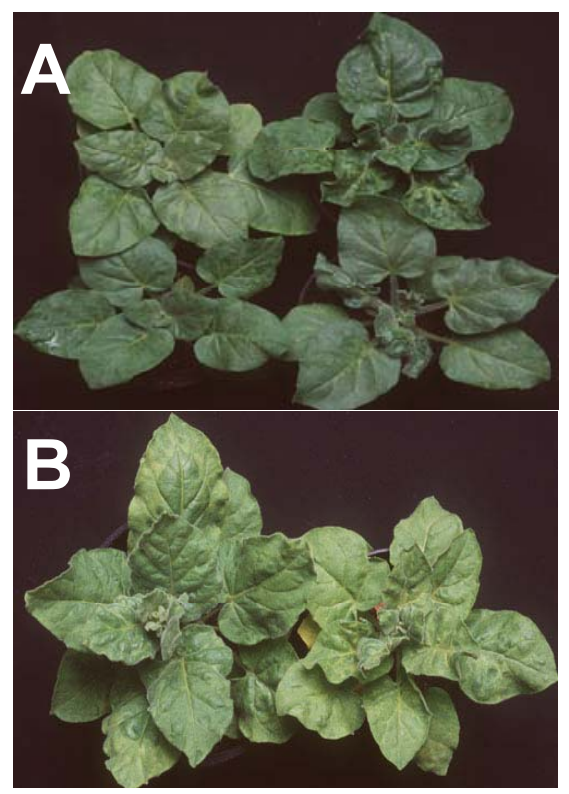

Fig. 3. Nicotiana glutinosa infected by Cucumber mosaic virus (CMV), Tomato aspermy virus (TAV), and various pseudorecombinant viruses containing the wild-type or chimeric mutants of the $2 b$ gene. A, Top row: Plants infected by either CMV RNAs 1,2 and 3 (C1C2C3) (left), or CMV RNAs containing a TAV $2 b$ gene in RNA 2 replacing the Q-CMV $2 b$ gene $\left(\mathrm{C} 1 \mathrm{C} 2{ }_{\mathrm{qt}} \mathrm{C} 3\right)$ (right). Bottom row: Plants infected by either TAV RNAs 1, 2, and 3 (T1T2T3) (left) or the chimeric pseudorecombinant virus $\mathrm{C} 1 \mathrm{C} 2 \mathrm{qt}_{\mathrm{T}} \mathrm{T}$ (right). B, Plants infected by either the chimeric pseudorecombinant virus $\mathrm{C} 1 \mathrm{C} 2_{\mathrm{qw}} \mathrm{T} 3$ (left) or the chimeric virus $\mathrm{C} 1 \mathrm{C} 2{ }_{\mathrm{qw}} \mathrm{C} 3$ (right), in which qw represents the $2 b$ gene from the WAII-strain of CMV replacing the $2 b$ gene of Q-CMV. replication of this modified RNA 3 was detected by confocal laser scanning microscopic visualization of the GFP. As a positive control, the $C P$ gene in pQCD3 was also replaced with the gene encoding the GFP. Both of these modified RNA 3 plasmids, pCass1T3GFP and pQCD3GFP, containing the GFP gene in place of the $C P$ gene were mixed with pQCD1 and pQCD2qt2 and were inoculated to $N$. clevelandii plants. Replication of the various combinations of inocula was detected by the presence of green fluorescent single-cell foci of infection (Fig. 4 and data not shown), showing similar intensities of GFP accumulation for infection by $\mathrm{C} 1 \mathrm{C} 2_{\mathrm{q} 22} \mathrm{C} 3_{\mathrm{GFP}}$ (Fig. 4A) and $\mathrm{C} 1 \mathrm{C} 2_{\mathrm{qt} 2} \mathrm{~T} 3_{\mathrm{GFP}}$ (Fig. 4B). Foci of infection of similar intensities also were observed when pQCD2qt2 in the inoculum was replaced with either pQCD2 or pQCD2qt1 (data not shown). Thus, the inability of $\mathrm{C} 1 \mathrm{C} 2_{\mathrm{qt} 2} \mathrm{~T} 3$ to establish infection detectable by Northern blot hybridization analysis (Fig. 2) was not due to a failure of the modified virus to support the replication of TAV RNA 3. Rather, this failure was most likely a consequence of the inability of such viruses to move from the initially infected cells to adjacent cells in the inoculated leaves.

\section{The $2 \mathrm{~b}$ gene of a hypervirulent CMV strain} also enhances the virulence but not the RNA accumulation of the CMV-TAV pseudorecombinant virus.

An alternative approach to verifying the role of the $2 \mathrm{~b}$ protein in hypervirulence involved replacing the whole TAV $2 b$ ORF in pQCD2qt2 with the $2 b$ ORF from the hypervirulent CMV strain WAII-CMV to generate pQCD2qw (Fig. 1). Coinoculation of pQCD2qw, pQCD1, and pCass1T3 yielded a virus, $\mathrm{C} 1 \mathrm{C} 2_{\mathrm{qw}} \mathrm{T} 3$, that infected all the plant species tested above and induced severe systemic mosaic symptoms on these species (Table 1, Fig. 3B, and data not shown). However, in contrast to observations made with $\mathrm{C} 1 \mathrm{C} 2 \mathrm{qtC} 3$ vs. C1C2qtT3, RNAs 1 and 2 generated from $\mathrm{C} 1 \mathrm{C} 2_{\mathrm{qw}} \mathrm{T} 3$ accumulated to levels comparable to those generated from $\mathrm{C} 1 \mathrm{C} 2_{\mathrm{qw}} \mathrm{C} 3$ (Fig. 2A, lane 13 vs. lane 12).

As expected, the nucleic acids extracted from the plants infected with $\mathrm{C} 1 \mathrm{C} 2_{\mathrm{qw}} \mathrm{T} 3$ showed hybridization to TAV RNAs 3 and 4 with the TAV-specific probe (Fig. 2B, lane 13 and data not shown). However, these same samples also showed hybridization to RNAs 3 and 4 as well as RNAs 1 and 2 with the CMV-specific probe (Fig. 2A, lane 13 and data not shown). RNAs 3 and 4 detectable by the CMV-specific probe in these samples also were larger than those of CMV RNAs 3 and 4 (Fig. 2A, lane 13 vs. lane 12) and were the same size as expected for TAV RNAs 3 and 4. Characterization of the $3^{\prime}$ $1,200 \mathrm{nt}$ of these RNAs by reverse transcription-polymerase chain reaction (RT-PCR) and sequencing using various combinations of primers showed that the recombinant RNAs consisted of TAV RNAs 3 and 4 but with the sequence of approximately $300 \mathrm{nt}$ of the $3^{\prime}$ terminal nontranslated region (NTR) derived from CMV. In addition, there were RT-PCR products obtained representing the parental sequences of TAV RNAs 3 and 4 (data not shown). Thus, there was a mixture of TAV RNAs 3 plus 4 in these plants, some containing the $3^{\prime}$ NTR of TAV and some containing the $3^{\prime}$ NTR of CMV. This may have had some effect on altering the accumulation profiles of the various RNAs, resulting in a large increase in TAV RNAs 3 and 4 accumulation (Fig. 2B, lane 13 vs. lane 5), with a corresponding decrease in accumulation of CMV RNAs 1 plus 2 (Fig. 2A, lanes 13 vs. lane 5). The detailed characterization of the recombinants and the factors involved in their generation will be described elsewhere.

The TAV and WAII-CMV 2b ORFs share only 53.4\% identity at the nucleotide level. Therefore, using a different $2 b$ gene, the above data again showed that the $2 b$ gene determined the level of virulence but did not directly affect the level of 
RNA accumulation. Moreover, the above results are inconsistent with any proposed role of the nucleotide sequence of the $2 b$ gene itself being required to promote viral infection. Thus, we conclude that both viral infection and hypervirulence were determined only by the $2 \mathrm{~b}$ protein rather than by other factors, such as either the $2 b$-gene sequence or the C-terminal 41 amino acids encoded by the TAV $2 a$ gene.

\section{DISCUSSION}

Pseudorecombinant viruses involving exchange of RNA 3 can be constructed between CMV and TAV (Habili and Francki 1974; Masuta et al. 1998; Rao and Francki 1981; Perry and Francki 1992; Sackey and Francki 1990; Salánki et al. 1997). However, it is apparent that they are not as competitive as the parental viruses (Sackey and Francki 1990; Perry and Francki 1992). This lack of competitiveness may reflect differences in the ability of the various proteins encoded by the two viruses to function together optimally to facilitate movement of viral RNAs from cell to cell and through the vasculature. Alternatively, there may be a requirement for direct, coordinated interactions between these proteins and specific host components. In either case, a lack of coordinated functions could lead to differences in the accumulation profiles and the virulence of the resulting viruses. In the case of the pseudorecombinants examined here, it is apparent that there were several effects on RNA accumulation. First, in many cases, the presence of RNA 3 from TAV caused a stimulation in the levels of accumulation of the CMV RNAs 1 or 2 (Fig. 2A, lanes 5 and 6 vs. lanes 2 and 6 , respectively). The exceptions to this occurred when the $2 \mathrm{~b}$ protein was not expressed (Fig. 2A, lanes 9 and $11 \mathrm{vs.}$ lanes 8 and 10) or when it was derived from the more virulent WAII-CMV (Fig. 2A, lane 13 vs. lane 12), although in each of these cases, further differences were seen. Second, those pseudorecombinants that showed infection in plants, with the exception of $\mathrm{C} 1 \mathrm{C} 2_{\mathrm{qw}} \mathrm{T} 3$ (Fig. 2B, lane 13), showed similar levels of accumulation of TAV RNA 3 to the wildtype T1T2T3 and lower levels of accumulation of TAV RNA 4 than for the wild-type T1T2T3 (Fig. 2B, lanes 5 and 7 vs. lane 3). These differences in RNA accumulation levels had no effect on virulence vis-à-vis the corresponding virus containing CMV RNA 3 (Table 1 and Fig. 3B). On the other hand, the source of the $2 b$ gene showed considerable affect on the level of virulence (Table 1 and Fig. 3). Thus, in the cases examined here, the presence of a variant $2 b$ gene caused a direct effect on the virulence of the virus, irrespective of the source of the RNA 3 (Table 1 and Fig. 3), and the virulence was unrelated to any effects on accumulation of the viral RNAs (Fig. 2). These latter observations are consistent with the analysis done in a previous study on virus levels and the timecourse of viral RNA accumulation for viruses differing in virulence on several hosts; i.e., $\mathrm{C} 1 \mathrm{C} 2 \mathrm{C} 3, \mathrm{C} 1 \mathrm{C} 2{ }_{\mathrm{qt}} \mathrm{C} 3$, and $\mathrm{C} 1 \mathrm{C} 2_{\mathrm{qw}} \mathrm{C} 3$ (Shi et al. 2002).

The CMV $2 b$ gene was shown not to be essential for either cell-to-cell or long-distance movement in several Nicotiana spp. (Ding et al. 1995a; Ji and Ding 2001; Soards et al. 2002). Thus, it was surprising that mutations that prevented the expression of the TAV $2 b$ gene from CMV RNA 2 also prevented the accumulation of viral RNAs in planta (Fig. 2) but not the replication (Fig. 4) of a chimeric pseudorecombinant virus containing TAV RNA 3 (i.e., C1C2 $2_{\mathrm{q} 2} \mathrm{~T} 3$ ). This indicates that the $2 \mathrm{~b}$ protein, whether from CMV or TAV, is required to facilitate a progressive infection of the pseudorecombinant viruses. This would tend to suggest a further interaction is required of the $2 \mathrm{~b}$ protein with RNA 3 , the $3 \mathrm{a}$ protein, or the CP of TAV to promote the cell-to-cell move- ment of $\mathrm{C} 1 \mathrm{C} 2_{\mathrm{qt} 2} \mathrm{~T} 3$ and $\mathrm{C} 1 \mathrm{C} 2_{\mathrm{qt} 3} \mathrm{~T} 3$, which is not required to facilitate the cell-to-cell movement of either $\mathrm{C} 1 \mathrm{C} 2{ }_{\mathrm{qt} 2} \mathrm{C} 3$ or $\mathrm{C} 1 \mathrm{C} 22_{\mathrm{qt} 3} \mathrm{C} 3$ (Table 1 and Fig. 2). Alternatively, the $2 \mathrm{~b}$ protein may be required to neutralize a host response elicited by either TAV RNA 3 or one of its encoded components that leads to a block in movement. The data presented here do not allow discrimination between these alternatives.

Differences between the ability of TAV and CMV homologous components to function in facilitating virus movement have been described before. A virus designated R1R2TR3, which consisted of RNAs 1 and 2 of the R-strain of CMV and a chimera of RNA 3, in which the 5' half derived from TAV RNA 3 and the $3^{\prime}$ half derived from R-CMV RNA 3, was not able to infect any of four host species, although the viral RNAs were able to accumulate in protoplasts from Nicotiana tabacum. On the other hand, a virus with the reciprocal RNA 3 chimera R1R2RT3 was able to infect all four host plant species tested (Salánki et al. 1997). Thus, there are other examples of chimeric pseudorecombinants between CMV and TAV that do not affect virus replication but do affect the ability of the virus to move cell to cell. This example does not allow further delimitation of the possible mechanism by which some chimeric pseudorecombinants are restricted in cell-to-cell movement, since there may be other factors operating to restrict the cell-to-cell movement of R1R2TR3. However, it does support the premise that pseudorecombinant viruses and chimeric viruses are not, in general, optimized for their interactions either between the viralencoded components, or with the host. Thus, such viruses would not be expected to compete very effectively with either of the parental viruses.
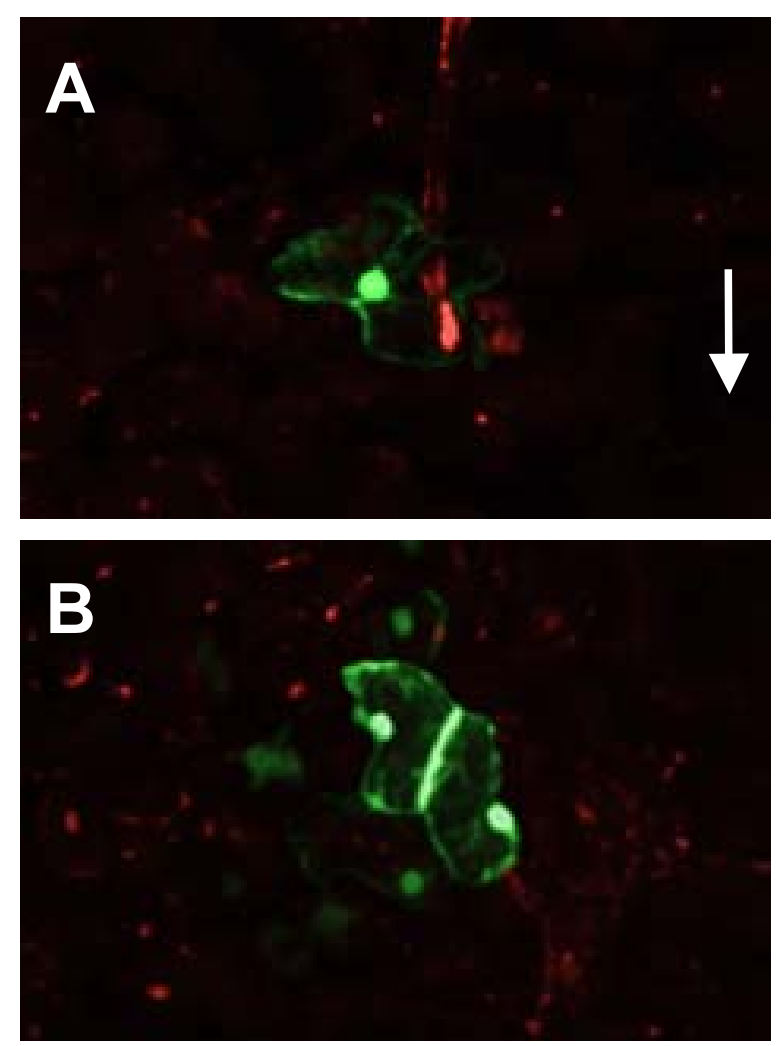

Fig. 4. Distribution of green fluorescent protein (GFP) in Nicotiana clevelandii epidermal cells. The viruses $\mathrm{C} 1 \mathrm{C} 2_{\mathrm{qt} 2} \mathrm{C} 3_{\mathrm{GFP}}$ and $\mathrm{C} 1 \mathrm{C} 2_{\mathrm{qt} 2} \mathrm{~T} 3_{\mathrm{GFP}}$ were inoculated to $N$. clevelandii plants. At five days postinoculation, the inoculated leaves were viewed by confocal laser scanning microscopy. Fluorescence images due to expression of the GFP were obtained from epidermal cells infected with either $\mathbf{A}, \mathrm{C} 1 \mathrm{C} 2_{\mathrm{qt} 2} \mathrm{C} 3_{\mathrm{GFP}}$ or $\mathbf{B}, \mathrm{C} 1 \mathrm{C} 2_{\mathrm{qt} 2} \mathrm{~T} 3_{\mathrm{GFP}}$. Noninfected cells did not show green fluorescence (arrow). 


\section{MATERIALS AND METHODS}

\section{Infectious cDNA plasmids.}

Infectious cDNA plasmids pQCD1, pQCD2, pQCD2qt, pQCD2qt1, pQCD2qt2, pQCD2qw, pQCD3, and pCass1T3 were described previously (Ding et al. 1995a, 1995b, 1996; Shi et al. 1997a, 2000). pQCD1, pQCD2, and pQCD3 contain the full-length cDNAs of RNAs 1, 2, and 3 of wild-type Q-CMV (Ding et al. 1995b), while pCass1T3 contains the full-length cDNA of RNA 3 of wild-type TAV (Shi et al. 1997a). Plasmids pQCD2qt, pQCD2qt1, pQCD2qt2, and pQCD2qw are derivatives of pQCD2, in which the $2 b$ gene or its mutant versions come from either TAV (pQCD2qt, pQCD2qt1, and pQCD2qt2 [Ding et al. 1996]) or WAIICMV (pQCD2qw [Shi et al. 2002]). The infectious cDNA plasmid pQCD2qt3 was also a derivative of pQCD2, constructed by adapting the same PCR-based strategy used previously for mutagenesis (Ding et al. 1996; Shi et al. 2002). Plasmids containing the GFP ORF in place of the CP ORF (pQCD3GFP and pCass1T3GFP, respectively) were prepared from pQCD3 and pCass1T3 by PCR mutagenesis and a 3piece ligation strategy, using the GFP gene from plasmid pS65T-C1 (Clontech, Basingstoke, U.K.) and appropriate primers (Canto et al. 1997). All the amplified regions in the clones were fully sequenced to ensure that the inserted sequences were as expected. All the above RNA 2 plasmids and their abbreviations are given in Figure 1.

\section{Plant materials and inoculation.}

The plant species $N$. clevelandii, N. glutinosa, L. esculentum, and $P$. floridana were all grown at $25^{\circ} \mathrm{C}$. Inoculation was carried out after a 24 -h dark pretreatment by rubbing the infectious cDNA clones or sterile water (as the control) with sterile Carborundum onto the surface of two or three fully expanded young leaves (Shi et al. 1997a). Unless specified otherwise, all the individual inocula consisted of the three genomic cDNA clones, each at a concentration of $10 \mu \mathrm{g}$ in $10 \mu \mathrm{l}$ water per plant. For each test, five, four-leaf-stage plants of each species were inoculated.

\section{Viral progeny RNA analysis.}

Total RNAs were extracted from infected plants and were analyzed by Northern blot hybridization as described previously (Shi et al. 1997b). Samples were first quantified by gel electrophoresis and by staining with ethidium bromide, and then, loadings for gels processed for blotting were equalized, relative to the level of the stained rRNAs. (The viral RNAs are all positioned behind various rRNA bands.) The probes were ${ }^{32} \mathrm{P}$-labeled transcript complementary to either nucleotides 2,287 to 2,386 of TAV RNA 3 or nucleotides 2,871 to 3,035 of Q-CMV RNA 2. These two riboprobes hybridize to all three genomic and the various subgenomic RNAs of either TAV or CMV, since the 3'-terminal sequences of the three genomic RNAs in each virus are highly conserved (Shi et al. 1997b).

Direct RNA sequencing was performed according to Fichot and Girard (1990). Templates used for sequencing were either the total RNAs extracted from infected plants or single RNAs purified via polyacrylamide gel electrophoresis and elution. DNA sequencing, using either PCR products or cDNA clones as templates, was carried out as described in Shi and associates (1997b).

\section{Detection of GFP fluorescence.}

Plants were inoculated with plasmids pQCD1 plus pQCD3GFP or pQCD1 plus pCass1T3GFP and were mixed with various RNA 2 variant plasmids as described above but with $2 \mu \mathrm{g}$ of plasmid per $10 \mu \mathrm{l}$ per plant. At three and five days after inoculation, the inoculated leaves were examined by confocal laser scanning microscopy to visualize the GFP, as previously described (Canto et al. 1997). Digital images obtained with the confocal microscope were processed with Adobe Photoshop software (Adobe Systems, San Jose, CA, U.S.A.).

\section{ACKNOWLEDGMENTS}

We thank X. Li for excellent technical assistance and S. H. Kim for advice and assistance. Work in Australia was supported by the Australian Research Council Special Research Center for Basic and Applied Plant Molecular Biology. Work in the United Kingdom was supported in part by contract no. QLK3-CT-2000-00361 from the European Commission. The Scottish Crop Research Institute is supported by a grantin-aid from the Scottish Executive Environment and Rural Affairs Department.

\section{LITERATURE CITED}

Brigneti, G., Voinnet, O., Li, W. X., Ji, L.-H., Ding, S.-W., and Baulcombe, D. C. 1998. Viral pathogenicity determinants are suppressors of transgene silencing in Nicotiana benthamiana. EMBO (Eur. Mol. Biol. Organ.) J. 17:6739-6746.

Canto, T., Prior, D. A. M., Hellwald, K. H., Oparka, K. J., and Palukaitis, P. 1997. Characterization of cucumber mosaic virus. IV. Movement protein and coat protein are both essential for cell-to-cell movement of cucumber mosaic virus. Virology 237:237-248.

Crescenzi, A., Barbarossa, L., Gallitelli, D., and Martelli, G. P. 1993. Cucumber mosaic cucumoviral populations in Italy under natural epidemic conditions and after a satellite-mediated protection test. Plant Dis. 77:28-33.

Ding, S.-W., Li, W. X., and Symons, R. H. 1995a. A novel naturally occurring hybrid gene encoded by a plant RNA virus facilitates long distance virus movement. EMBO (Eur. Mol. Biol. Organ.) J. 14:57625772

Ding, S.-W., Rathjen, J. P., Li, W. X., Swanson, R., Healy, H., and Symons, R. H. 1995b. Efficient infection from cDNA clones of cucumber mosaic cucumovirus RNAs in a new plasmid vector. J. Gen. Virol. 76:459-464.

Ding, S.-W., Shi, B.-J., Li, W. X., and Symons, R. H. 1996. An interspecies hybrid RNA virus is significantly more virulent than either parental virus. Proc. Natl. Acad. Sci. U.S.A. 93:7470-7474.

Fichot, O., and Girard, M. 1990. An improved method for sequencing of RNA templates. Nucleic Acids Res. 18:6162.

Fraile, A., Alonso-Prados, J. L., Aranda, M. A., Bernal, J. J., Malpica, J. M., and García-Arenal, F. 1997. Genetic exchange by recombination or reassortment is infrequent in natural populations of a tripartite RNA plant virus. J. Virol. 71:934-940.

Guo, H. S., and Ding, S.-W. 2002. A viral protein inhibits the long range signaling activity of the gene silencing signal. EMBO (Eur. Mol. Biol. Organ.) J. 21:398-407.

Habili, N., and Francki, R. I. B. 1974. Comparative studies on tomato aspermy and cucumber mosaic viruses. III. Further studies on relationship and construction of a virus from parts of the two viral genomes. Virology 61:443-449.

Ji, L.-H., and Ding, S.-W. 2001. The suppressor of transgene RNA silencing encoded by Cucumber mosaic virus interferes with salicylic acid-mediated virus resistance. Mol. Plant-Microbe Interact. 14:715724.

Li, H. W., Lucy, A. P., Guo, H. S., Li, W. X., Ji, L.-H., Wong, S. M., and Ding, S.-W. 1999. Strong host resistance targeted against a viral suppressor of the plant gene silencing defense mechanism. EMBO (Eur. Mol. Biol. Organ.) J. 18:2683-2691.

Lucy, A. P., Guo, H. S., Li, W. X., and Ding, S.-W. 2000. Suppression of post-translational gene silencing by a plant viral protein localized in the nucleus. EMBO (Eur. Mol. Biol. Organ.) J. 19:1672-1680.

Masuta, C., Ueda, S., Suzuki, M., and Uyeda, I. 1998. Evolution of a quadripartite hybrid virus by interspecific exchange and recombination between replicase components of two related tripartite RNA viruses. Proc. Natl. Acad. Sci. U.S.A. 95:10487-10492.

Mayers, C. N., Palukaitis, P., and Carr, J. P. 2000. Subcellular distribution analysis of the cucumber mosaic virus 2 b protein. J. Gen. Virol. 81: 219-226.

Perry, K. L., and Francki, R. I. B. 1992. Insect-mediated transmission of mixed and reassorted cucumovirus genomic RNAs. J. Gen. Virol. 73:2105-2114.

Rao, A. L. N., and Francki, R. I. B. 1981. Comparative studies on tomato aspermy and cucumber mosaic viruses. VI. Partial compatibility of 
genomic segments from the two viruses. Virology 114:573-575.

Sackey, S. T., and R. I. B. Francki. 1990. Interactions of cucumoviruses in plants: Persistence of mixed infections of cucumber mosaic and tomato aspermy viruses. Physiol. Mol. Pant Pathol. 36:409-419.

Salánki, K., Carrère, I., Jacquemond, M., Balázs, E., and Tepfer, M. 1997. Biological properties of pseudorecombinant and recombinant strain created with cucumber mosaic virus and tomato aspermy virus. J. Virol. 71:3597-3602.

Shi, B.-J., Ding, S.-W., and Symons, R. H. 1997a. Plasmid vector for cloning infectious cDNAs from plant RNA viruses: High infectivity of cDNA clones of tomato aspermy cucumovirus. J. Gen. Virol. 78:1181-
1185.

Shi, B.-J., Ding, S.-W., and Symons, R. H. 1997b. Two novel subgenomic RNAs derived from RNA 3 of tomato aspermy cucumovirus. J. Gen. Virol. 78:505-510.

Shi, B.-J., Palukaitis, P., and Symons, R. H. 2002. Differential virulence by strains of Cucumber mosaic virus is mediated by the $2 b$ gene. Mol. Plant-Microbe Interact. 15: 947-955.

Soards, A. J., Murphy, A. M., Palukaitis, P., and Carr, J. P. 2002. Virulence and differential local and systemic spread of Cucumber mosaic virus in tobacco are affected by the CMV $2 \mathrm{~b}$ protein. Mol. PlantMicrobe Interact. 15: 647-653. 